\title{
Sexual allure and the Tudors
}

Lesley Smith

\section{Henry VIII's legacy}

Henry VII was definitely a medieval king, which Henry VIII was determined not to be. Sophisticated and learned Europe was said to be 100 years in advance of England, which was still clinging to the old ways. The "green and sceptred isle" was not attractive to the artists and philosophers who had found a rich and glittering haven in other courts. The eighth Henry was a handsome teenage king with golden hair. An Olympian figure, not least because he was 6 foot 2 inches tall, while the average man of the early 16th century was around 5 foot 5 inches. Later, in Holbein's portrait we see him massive and magnificent, legs apart, hands on hips, a full manly challenge with a huge codpiece to match. Elevated to kingship with power over Church and land, Henry was highly sexed and predatory but also a man of the Renaissance. He succeeded in putting England on the map whilst encouraging thinkers such as Thomas More and Erasmus of Rotterdam. Henry had to win any battle he was involved in, including the one with the Pope. The chase and the catching of the creature were all. The slaughter often followed soon after.

\section{The Elizabethan period}

Queen Elizabeth, the last Tudor monarch, changed a great deal when she came to the throne of England. This article particularly refers to her reign. Gloriana was a creature determined not to be caught in the chase. The Queen would be "master and mistress in her own kingdom". She became a huntress, Diana the moon goddess, allowing no man in her temple. There is no real proof that Elizabeth lost her virginity, although much work has been done over the centuries to try and prove otherwise.

The red-haired Queen was watched intently in this country and overseas. She was a profound influence on the up-and-coming middle classes, not least because she was actually seen by so many people as she moved around her country with a vast entourage.

Elizabeth was highly educated, with a quick and analytical mind. A natural politician, honed in the fires of fear of a childhood peppered with dead and/or humiliated stepmothers. As a young teenager, she had been physically examined following the Tom Seymour scandal and declared virgo intacta. As a queen, Elizabeth wanted England to be healthy and grow in the bright light of peace, the only European monarch without any martial ambitions. She did not hold out her virgin state as an ideal, far from it, as she enjoyed playing matchmaker - on her own terms, of course.

Court was generally thought better behaved than in her father's time, and certainly more sophisticated, but we know that Elizabeth enjoyed a bawdy play on Cheapside amidst a cheering, roaring crowd.

Elizabeth's strategy of avoiding war meant the gathering of monies for the treasury through taxes, following a massive growth in trade. Society was held together by a complex network of patronage reaching right through the social strata. It also meant, of course, that the men were at home working in this euphoric atmosphere of

J Fam Plann Reprod Health Care 2006; 32(2): 129-130

Tutbury Castle, Tutbury, UK

Lesley Smith, Curator

Correspondence to: Lesley Smith, Tutbury Castle, Tutbury, Staffordshire DE13 9JF, UK. E-mail: info@tutburycastle.com
England's economic growth. Sex became a happy hobby, with poems and plays extolling its wonders. John Donne, Spencer and Shakespeare all include sex in their work, sometimes in extraordinary detail. The first pornography seen since the Romans left these shores went on sale to those who could afford it.

\section{Appearance matters}

Costume, in the late 16th century, became the ultimate sign of sexual allure, partly because it was also a display of wealth and power. Some young people arrived at court literally wearing a whole family fortune on their backs in a desperate attempt to be noticed. The same applied to the lesser court of commerce where a man or woman might win themselves a great match.

The clothes were exaggerated and decorated as never before. Both sexes strutted like peacocks. Stomanchers were lined with steel, as were the great Farthingales beneath. Clothes were made of wool or, for the rich, of silks, heavy velvets and furs. Bum rolls and peascods stuffed with horsehair were worn to draw attention to small waists. Breasts were held high and often fully exposed, some with painted nipples. There is even some evidence of nipple piercing with pearls to suggest milk falling from fertile breasts. Many women, and some men, painted their faces with dangerous white lead in oil, sometimes mixed with a little arsenic to make the skin translucent, like a child's, with pale blue veins beneath the eyelids. A little too much arsenic and the skin would be very translucent indeed! Wigs and hairpieces sold well to all who could afford them and hair colour sales boomed - mostly made of urine, henna or liquorice. Exotic sandalwood competed against homely lavender in an attempt to cover the only too evident stink of humanity. The people of England were making an outward and visible show of their wealth and sexuality.

\section{Great Bed of Ware}

The Great Bed of Ware stands as a massive four-poster monument to England's rollicking days of the late 16th century. Said to have been built in 1590, it measures 10 feet by 11 feet, can sleep more than 15 people at a time, and carries the signatures of many who used the bed (those who could write!) carved into its huge wooden posts. The bed is beautifully carved and a great wonder of its day, a monument indeed. [NB. The Great Bed of Ware can be seen at the Victoria and Albert Museum in London, UK and is well worth a visit.]

\begin{tabular}{|ll|}
\hline Box 1: Glossary of terms & \\
Back door & Anal intercourse \\
Bawd & Pimp, keeper of a stew \\
Buxom & Generous (that's all) \\
Commiter & Client of a prostitute \\
Cunny & Vagina \\
Dell & Virgin female vagrant \\
Doxy & Sexually experienced female vagrant \\
Drab & Whore, slut \\
Ferret & Cheat \\
Ingle & Catamite \\
Light-heeled & Promiscuous \\
Mistress 'o the game & Prostitute \\
Pistol & Penis \\
Roaring girl & Lesbian \\
Stale & Prostitute \\
Stew & Whorehouse \\
To occupy & Sexual intercourse \\
Trug & Whore, slut \\
Vaulting house & Whorehouse \\
Winchester goose & Prostitute \\
\hline
\end{tabular}




\section{Elizabethan society}

Women were, at the end of Elizabeth's reign, more powerful than they had ever been before. Adultery, incest and samesex coupling are all recorded in one form or another from legal court hearings or by pamphleteers of the day. It seems there was plenty of premarital sex, but as the vast majority of the poor had 'handfasting' ceremonies without any legal witness or Church function, it depends on what is meant by the term 'marriage'. Known illegitimate births, recorded as such, reached a high peak in the mid-1590s.

It is vital to understand that Elizabethan society was extremely energetic compared to today because the great majority of the population were young people. The "movers and shakers' were often in their 20s, particularly in the early part of Elizabeth's reign, reflecting her own age group. In the last two decades of the 16th century, public records show that only $10 \%$ of the population of York attained the age of 40 years, which illustrates how very different society structures were then. Streets were noisy and colourful, with many recorded observations about fighting and shouting. The 'yobs' of the Elizabethan days were known by the indulgent term of 'roaring boys'. There is reference to lesbians being referred to as 'roaring girls' (see Box 1 for a glossary of terms).

\section{Brothels and adultery}

Whorehouses (or 'stews') thrived, with a wide range of services, from "virgins 4/-" to a "prostitute boy" at a rather more expensive rate. Sixpenny whorehouses are also referred to and seem to be the lower end of the market. Smarter brothels were licensed by the Bishops of Winchester from the 1160s. The Bishops held great swathes of property in Southwark, which earned them huge revenues, mostly from the stews. Professional prostitutes were commonly called "a Winchester goose" because they laid a golden egg. Stews were also a useful place to secrete female spies working for the likes of Sir Thomas Walsingham. Courtesans, often very beautiful, talented and rich, lay down for huge profit and occasionally securing for themselves a marriage and title.

There were laws in place to protect the innocent. The brothel must be painted white outside (possibly a reference to the whitened sepulchre) and the girls must have a white apron so no decent woman may be mistaken and approached. There were prosecutions for lewdness, which involved a carefully choreographed legalised whipping, or a visit to the stocks. Extreme cases involved the girls having their head shaved and being dragged behind a cart. The law needed to be seen to be kept now and again and perhaps they were prostitutes or bawds who threatened the legalised houses.

Adultery was punished by the person having to stand outside church for three Sundays in a row (the Trinity) wearing a long white robe, a white hat and carrying a white rod. Priests complained that some offenders clearly enjoyed wearing the robe and waved their rod salaciously at passers by. There were various other punishments including imprisonment, but these were rarely enforced which must have been a relief to Henry VIII.

\section{"Merrie England": then and now}

Elizabethan society was also known to be very affectionate compared with other countries in Europe, which rather belies the thinking that Englishmen are standoffish and cold. We know from the writings of Erasmus of Rotterdam when he visited in 1499: "They come to visit you, kisses again; they leave you, you kiss them all round. Should they meet you anywhere, kisses in abundance. In fine, wherever you move there was nothing but kisses." Erasmus obviously enjoyed the custom hugely and no wonder, as his portraits show a rather cadaverous type who might not get them otherwise. So here we have a "Merrie England", young and adventurous, affectionate and demonstrative, full of laws about sexual behaviour, of which many were ignored. In fact, there's little that's new.

\section{Future articles}

Readers interested in finding out more for themselves about the topics covered in this article should consult some of the publications listed in the Bibliography. The next article in this series is on 'Menstruation: Curse or Blessing?'.

\section{Acknowledgements}

The author would like to thank the following individuals for their help and advice: Dr R Arnott, Sub-Dean of Medicine and Director, The Medical School, University of Birmingham, Birmingham and Dr G Williams, Curator, British Museum, London, UK.

\section{Bibliography}

There are a large number of books on the 16th century. Below is listed a small selection to add to my series' recommended reading list. There is also a range of domestic papers available to read at the British Library that are both fascinating and time consuming for those readers who enjoy being detectives.

1 Prior, Mary (ed.). Women in English Society 1500-1800. London, UK: Routledge, reprinted 1991, 1996. A series of extremely well researched academic papers that include tables of statistics on births, deaths and marriages and stillborns.

2 Braithwaite, William S (ed.). The Book of Elizabethan Verse. London, UK: Chatto \& Windus, 1908. A golden collection of contemporary poems that illustrate how love and passion were presented by the poets of the day.

3 Salgado, Gamini. The Elizabethan Underworld. Yeovil, UK: Sutton Publishing, 2005. Gamini Salgado is a professor of English and this very well researched book adds new colour to the 16th century and is a great help in the translation of some work - which is not necessarily obvious, even in English!

4 Stone, Lawrence. The Family, Sex and Marriage in England 1500-1800. New York, NY: Harper \& Row, 1977. Lawrence Stone was a lecturer at University College, Oxford and a Fellow of Wadham College, Oxford. He went on to become Dodge Professor of History at Princetown University, New Jersey. One of the great interpretive pieces.

5 Herman, Eleanor. Sex with Kings. London, UK: HarperCollins, 2004. Spans 500 years of adultery, power and sex. Well sourced and utterly readable.

\section{About the Author}

Lesley Smith is an Elizabethan historian, currently studying for the degree of MPhil in the History of Medicine at Birmingham University Medical School. She has appeared in 14 television programmes including Tony Robinson's The Worst Jobs in History, and is currently working on an eight-part 1-hour major series on the Private Lives of Women.

In November 2005, Lesley spoke at The Guildhall, London, UK to an audience of more than 500 including gynaecologists, members of the House of Lords and a Health Minister on the occasion of the 75th anniversary of the fpa (Family Planning Association).

Lesley is well known as a public speaker and regularly startles her audiences when appearing in full Elizabethan costume and the dead-white authentic make-up of the 1580 s. Lesley's humorous and powerful delivery is encouraging many health professionals to find out more about the root of their profession.

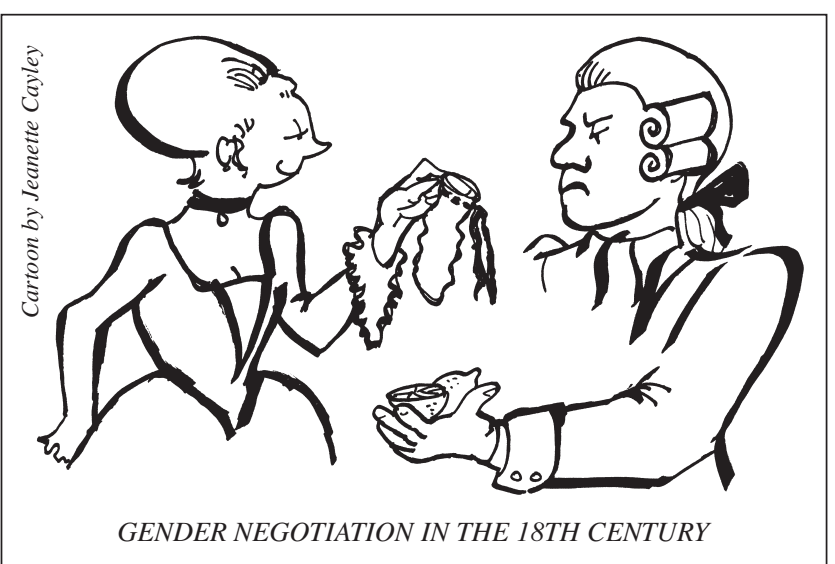

